Evaluation of ${ }^{137}$ Cs Body Burden in Inhabitants of Bryansk Oblast, Russian Federation, Where a High Incidence of Thyroid Cancer Was Observed after the Accident at the Chernobyl Nuclear Power Plant

Yui SEKITANI ${ }^{1}$, Naomi. HAYASHIDA ${ }^{1}$, Irina V. KAREVSKAYA ${ }^{2}$, Olga A. VASILITSOVA ${ }^{2}$, Alexander KOZLOVSKY ${ }^{3}$, Masanori OMIYA ${ }^{1}$, and Noboru TAKAMURA ${ }^{1 *}$

\title{
List of Institutions
}

${ }^{1}$ Department of Radiation Epidemiology, Nagasaki University Graduate School of Biomedical Sciences, Nagasaki 852-8523, Japan

${ }^{2}$ Bryansk Consultative-Diagnosis Center, Klincy City, Bryansk Oblast, Russian Federation

${ }^{3}$ Gomel State Medical University, Gomel, Belarus

\section{Corresponding Author}

Phone: $+81-95-819-7170$

Fax: $+81-95-819-7172$

E-mail: takamura@nagasaki-u.ac.jp

\section{Running title}

${ }^{137}$ Cs Body Burden in Bryansk, Russia 


\section{Abstract}

Evaluation of ${ }^{137} \mathrm{Cs}$ Body Burden in Inhabitants of Bryansk Oblast, Russian Federation, Where a High Incidence of Thyroid Cancer Was Observed after the Accident at the Chernobyl Nuclear Power Plant

Yui SEKITANI ${ }^{1}$, Naomi HAYASHIDA ${ }^{1}$, Irina V. KAREVSKAYA ${ }^{2}$, Olga A. VASILITSOVA ${ }^{2}$, Alexander KOZLOVSKY ${ }^{3}$, Masanori OMIYA ${ }^{1}$, and Noboru TAKAMURA ${ }^{1 *}$

To determine the current risk of internal radiation exposure after the Chernobyl accident, we evaluated the ${ }^{137} \mathrm{Cs}$ body burden of the inhabitants of Bryansk Oblast, Russian Federation, from 1998 to 2008. The study population is composed of 84,666 people who visited Bryansk No. 2 Hospital. A whole-body counter was used for measurement of ${ }^{137} \mathrm{Cs}$ body burden. ${ }^{137} \mathrm{Cs}$ concentration was significantly higher in the late period during the study and showed seasonal variation, suggesting that inhabitants may have consumed contaminated forest products. However, people with high annual exposure doses were quite rare during all years of the study. In conclusion, we showed that although internal radiation exposure from ${ }^{137} \mathrm{Cs}$ continues to this day in Bryansk Oblast, the annual exposure dose is low in almost all inhabitants. Because of the long half-life of ${ }^{137} \mathrm{Cs}$, long-term follow-up is necessary to monitor the health status and relieve the anxiety of the inhabitants around Chernobyl. 


\section{Introduction}

The accident at the Chernobyl Nuclear Power Plant (CNPP) in 1986 was the most severe in the history of the nuclear power industry, causing a huge release of radionuclides over large areas of the Republic of Belarus, Ukraine, and the Russian Federation. The CNPP accident led to a high level of radioactive contamination in the western districts of Bryansk Oblast, which is an administrative unit of a territory in the Russian Federation. This area is 150 to $250 \mathrm{~km}$ northeast of the nuclear power plant, and the contamination in the area varied from 0.03 to $3.7 \mathrm{MBq} / \mathrm{m}^{2}$ (1)

One of the principal radionuclides released by the Chernobyl accident was ${ }^{131} \mathrm{I}$, to which exposure was significant for the first few months. Fallout of radioactive iodine led to considerable thyroid exposure of local inhabitants through inhalation and ingestion of foodstuffs containing high levels of radioiodine ${ }^{(2,3)}$. Because the thyroid gland is one of the organs most susceptible to radiation exposure, childhood thyroid cancer caused by radioactive iodine fallout is one of the main health impacts of the accident ${ }^{(3-6)}$. Drinking milk from cows that ate contaminated grass immediately after the accident was the principal reason for the high doses to the thyroid glands of children, and many children subsequently developed thyroid cancer ${ }^{(4)}$. By 2002, more than 4000 thyroid cancer cases had been diagnosed among children 0 to 14 years of age at the time of the accident and another 1000 cases among those exposed between the ages of 15 and 17 years who resided in the three most contaminated regions following the Chernobyl accident: Belarus, Ukraine, and four Oblasts of the Russian Federation ${ }^{(3,7)} \cdot{ }^{131}$ I was concentrated primarily in the thyroid gland, with children and adolescents receiving higher doses than adults because of their greater milk consumption and higher sensitivity to radiation exposure ${ }^{(3)}$.

In the early months after the accident, the levels of radioactivity of agricultural plants and plant-consuming animals were dominated by surface deposits of radionuclides ${ }^{(2)}$. The deposition of radioiodine represented the most immediate concern; however, the problem was confined to the first 2 months after the accident because of the fast decay of radioiodine. After the early phase of direct 
deposit, uptake of radionuclides from soil through plant roots became increasingly important. Since 1987, radioisotopes of cesium, ${ }^{137} \mathrm{Cs}$ and ${ }^{134} \mathrm{Cs}$, led to the greatest problems following the decay of radioactive iodine. In particular, ${ }^{137} \mathrm{Cs}$ has caused continuous contamination due to its long half-life of 30 years ${ }^{(2)}$.

There have been many post-Chernobyl studies of leukemia and cancer morbidity in the populations of the contaminated areas. However most studies had methodological limitations and lacked statistical power. Therefore there is no convincing evidence at present that the incidence of leukemia or cancer (other than thyroid) has increased in children, those exposed in-utero, or adult residents of the

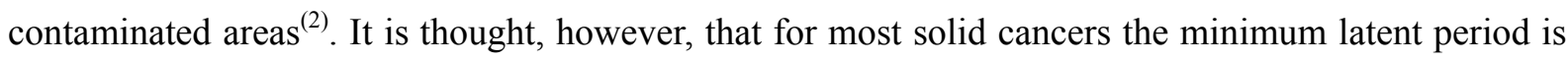
likely to be much longer and it may be too early to evaluate the full radiological impact of the accident.

Previously, Hoshi et al. evaluated ${ }^{137} \mathrm{Cs}$ body burden in children residing in Bryansk Oblast during 1991 to 1996 within the framework of the Chernobyl Sasakawa Medical Health and Medical Cooperation Project, and showed a relationship between ${ }^{137} \mathrm{Cs}$ specific activities and the level of soil contamination with ${ }^{137} \mathrm{Cs}$. They also found a strong seasonal effect on ${ }^{137} \mathrm{Cs}$ body burden ${ }^{(1)}$.

In this study, we aim to evaluate the ${ }^{137} \mathrm{Cs}$ body burden of the inhabitants of Bryansk Oblast from 1998 to 2008 in order to determine the current health risk of internal radiation exposure in inhabitants residing in this area. 


\section{Subjects and Methods}

Screening of ${ }^{137} \mathrm{Cs}$ body burden by whole-body counter (WBC) was conducted from 1998 to 2008 at Bryansk No. 2 Hospital, which is located in Klincy City, Bryansk Oblast, Russian Federation, an area strongly affected by the accident at the CNPP (Fig. 1). Annual numbers of study participants are shown in Table 1. The number of participants was around 6,000 each year, except for 2001 to 2003 (around 10,000). From 1998 to 2002, most of the participants were under age 20 years at the time of measurement. After 2004, the number of middle-aged participants increased and the age distribution spread. Throughout all years, the numbers of male and female participants were almost the same. The total number of participants during 1998 to 2008 was 84,666 .

A $\gamma$-spectrometer Model 101 equipped with a collimator (Aloka Co., Ltd, Tokyo, Japan) was used for measurement of ${ }^{137} \mathrm{Cs}$ body burden. The counter was equipped with a NaI (T1) detector $7.6 \mathrm{~cm}$ in diameter and $7.6 \mathrm{~cm}$ in thickness, with a 5-cm-thick lead shield. The detector was designed to face the abdomen of the examinee sitting in a chair, with adjustable height and angle. The back and the seat of the sliding chair were shielded with lead plates. Gamma rays emitted from the examinee's body were counted by means of the detector and analyzed with a 240-channel spectrometer JSM-102. In accordance with the manufacturer's instructions, ${ }^{137} \mathrm{Cs}$ body burden $(\mathrm{Bq})$ was calculated, and obtained values were corrected for body weight $(\mathrm{Bq} / \mathrm{kg})$. The minimum detectable ${ }^{137} \mathrm{Cs}$ body burden was 270 Bq. The procedures employed for calibration of ${ }^{137} \mathrm{Cs}$ counting and whole body monitoring have been published in detail elsewhere ${ }^{(8)}$.

We estimated the annual exposure dose, based on the effective dose coefficient $2.5^{*} 10^{-3} \mathrm{mSv} / \mathrm{year}$ per $\mathrm{Bq} / \mathrm{kg}^{(1)}$. We also calculated the 50-year exposure doses commitment with the ${ }^{137} \mathrm{Cs}$ peak, according to the formula $\left(3.821{ }^{137} \mathrm{Cs}\right.$ concentration $(\mathrm{Bq}) * 70 / 4,000,000 /$ body weight $\left.(\mathrm{kg})\right)$ developed by Shimasaki and Okumura, based on the physiological half-life of ${ }^{137} \mathrm{Cs}^{(9)}$.

Data are expressed as median $\left(25^{\text {th }}-75^{\text {th }}\right.$ percentile) or median (minimum-maximum). Statistical analysis was performed using Microsoft Excel $^{\circledR}$ (Microsoft Corporation, Redmond, WA, USA) and 
SPSS Statistics $17.0^{\circledR}$ (SPSS Japan, Tokyo, Japan). Probability values less than 0.05 were considered indicative of statistical significance. 


\section{Results}

${ }^{137}$ Cs concentrations between 1998 and 2008 in Bryansk Oblast are shown in Fig. 2. From 1998 to 2003, the ${ }^{137} \mathrm{Cs}$ concentration decreased gradually, but the trend changed to an increase in 2004 . The median value was between 20 and $50 \mathrm{~Bq} / \mathrm{kg}$ throughout the study period. The maximum value varied considerably, from 600 to $5400 \mathrm{~Bq} / \mathrm{kg}$. When we evaluated the ${ }^{137} \mathrm{Cs}$ concentration in each year, we found that the values in the first two years (1998 and 1999) were significantly higher than in other years except for 2008 .

Table 2 shows the seasonal differences in ${ }^{137} \mathrm{Cs}$ concentration from 1998 through 2008 . The ${ }^{137} \mathrm{Cs}$ concentration was statistically higher in autumn than other seasons in every year after 2004 (analysis of variance followed by Tamhane test). When the study period was divided into three periods (i.e., 1998-2001, 2002-2005, and 2006-2008), we found that ${ }^{137}$ Cs concentration was the highest in autumn (September-November), except for 1998 to 2001, during which time ${ }^{137} \mathrm{Cs}$ concentration was the highest in summer (June-August) (Table 3).

Table 4 shows the calculated annual internal exposure dose, based on the effective dose coefficient. Median annual internal exposure doses during 1998 to 2008 were between 0.06 and $0.11 \mathrm{mSv} / \mathrm{year}$. In 1998, 98 inhabitants (1.44\%) exceeded $1 \mathrm{mSv} /$ year, which is the ICRP dose limit for the general public $^{(10)}$, and one inhabitant exceeded $5 \mathrm{mSv} /$ year. The number of people with doses higher than 1 $\mathrm{mSv} /$ year decreased gradually, and none of the inhabitants exceeded $1 \mathrm{mSv} / \mathrm{year}$ in 2008. People with high internal doses, in excess of $5 \mathrm{mSv}$, were quite rare during all years. On the other hand, the highest annual exposure dose (13.5 mSv/year) was observed in 2004.

The calculated 50-year exposure doses commitment of ${ }^{137} \mathrm{Cs}$ during 1998 to 2008 are shown in Table 5. Median values decreased from $2.8 \mathrm{mSv}$ in 1998 to $1.6 \mathrm{mSv}$ in 2003, whereas a relatively high dose was observed in 2004 and the most recent 2 years $(2.6 \mathrm{mSv}$ in $2004,2.6 \mathrm{mSv}$ in 2007, and 2.9 $\mathrm{mSv}$ in 2008). 


\section{Discussion}

Contamination of soil, vegetation, and water with ${ }^{137} \mathrm{Cs}$ is the main factor in internal radiation exposure of inhabitants due to its long half-life ${ }^{(3)}$. As shown in Fig. 2, the ${ }^{137} \mathrm{Cs}$ concentration evaluated by WBC showed a slow decrease from 1998 to 2003, but it increased after 2004. Inhabitants of Zlynkovskii area, which is known to be a highly contaminated area, were included in this study after 2003, and this may be the reason for the increase in ${ }^{137} \mathrm{Cs}$ concentration in the late period.

Previously, Hoshi et al. pointed out that there was a strong seasonal difference in ${ }^{137} \mathrm{Cs}$ concentration due to the seasonal change in diet and that concentrations were higher in autumn than spring ${ }^{(1)}$. In autumn, ${ }^{137} \mathrm{Cs}$ body burden sometimes has been reported to be 60 to $100 \%$ higher than during spring and summer, mainly due to an increased intake of forest products such as mushrooms ${ }^{(11-13)}$. As shown in Table 2, the ${ }^{137} \mathrm{Cs}$ concentration was the highest in autumn every year after 2004. These results suggest that inhabitants may have consumed products derived from the contaminated forests. Although consumption of local foodstuffs produced in contaminated areas has been banned, there is evidence suggesting that forest products are widely consumed in Bryansk Oblast and contribute to the increase of ${ }^{137} \mathrm{Cs}$ internal body burden. On the other hand, relatively high ${ }^{137} \mathrm{Cs}$ body burden in the summer during 1998 to 2001 may be due to the differences in sample size in different seasons: i.e., the sample size is quite small in summer compared to other seasons due to the summer vacation.

The diet of the population is an important social factor that determines the intake of radionuclides. The accident strongly influenced the diet of the inhabitants around the CNPP, especially with regard to consumption of milk and dairy products of local origin. Travnikova et al. showed that the individual content of ${ }^{137} \mathrm{Cs}$ in the bodies of inhabitants living in a village of Bryansk Oblast correlated with consumption of milk during the initial period after the accident and with consumption of forest mushrooms during the subsequent period ${ }^{(14)}$. Further study is necessary to correlate the internal radiation exposure with the increase of consumption of wild food products. 
Our results showed that the frequency of relatively high doses (i.e., $>1 \mathrm{mSv} /$ year) of estimated annual internal exposure is quite small. Thornberg et al. reported that the mean effective dose from external and internal radiation exposure due to ${ }^{137} \mathrm{Cs}$ and ${ }^{134} \mathrm{Cs}$ deposition to people in villages in Bryansk Oblast varied between 1.2 and $2.5 \mathrm{mSv} /$ year from 1990 to $2000^{(15)}$. Thornberg et al. estimated that the contribution from the internal dose to the total dose was between 17 and $75 \%$, depending on the village. In our current study, which was performed during 1998 to 2008, estimated annual internal exposure dose was fairly low, probably due to the late study period ${ }^{(15)}$.

The 50-year exposure dose from natural background radiation has been calculated as $120 \mathrm{mSv}(2.4$ mSv per year) ${ }^{(16)}$. During 1998 to 2008, all median values were much less than $120 \mathrm{mSv}$, and in 2007 and 2008, no inhabitants exceeded $120 \mathrm{mSv}$. Thornberg et al. estimated that the cumulative effective dose from internal radiation exposure was 30 to $40 \mathrm{mSv}$ for 70 years. In addition, the sum of the cumulative effective doses of internal and external radiation exposure was estimated at 70 to $90 \mathrm{mSv}$ for 70 years ${ }^{(15)}$. Although this value differs from the findings of our current study because of the different formulas used for estimation; i.e., the annual effective dose from internal exposure was calculated as $r_{\text {sum }}(m) \cdot \frac{A}{m} ; r_{\text {sum }}$ is the dose rate coefficient $(\mathrm{mSv} /$ year per $\mathrm{kBq} / \mathrm{kg})$ for the total content of ${ }^{137} \mathrm{Cs}$ and ${ }^{134} \mathrm{Cs}$ in a person with body mass $m(\mathrm{~kg})$ and $\mathrm{A}$ is the measured sum of activities of ${ }^{137} \mathrm{Cs}$ and ${ }^{134} \mathrm{Cs}$ in the body $(\mathrm{kBq})$, the current radiation risk posed by continuing to reside around the CNPP is not considered to be critical.

From the radiological point of view, two of the most important radionuclides were ${ }^{131} \mathrm{I}$, which delivered doses to the thyroid during the first few months after the accident, and ${ }^{137} \mathrm{Cs}$, which is responsible for the whole-body doses that have been delivered at low rates to the population and that will continue to be delivered for the next several decades ${ }^{(17)}$. Although the health effects of internal exposure to ${ }^{137} \mathrm{Cs}$ are still controversial, there is no precedent for the Chernobyl accident and therefore long-term follow-up of ${ }^{137} \mathrm{Cs}$ internal body burden around this area is necessary to monitor the health status of the inhabitants and relieve the anxiety in this area. 
One of the limitations of this study is that we evaluated only internal body burden by WBC. For accurate risk assessment from radiation exposure around the CNPP, a further comprehensive approach will also be needed. This study was performed only in Bryansk Oblast; therefore, further study in other areas around the CNPP is necessary. Also, we could not evaluate the differences among places of residence in Bryansk Oblast including the highly contaminated Zlynkovskii area. Finally, we could not evaluate who repeatedly came for examination.

In conclusion, we showed that while internal radiation exposure by ${ }^{137} \mathrm{Cs}$ continues in Bryansk Oblast even today, the annual internal exposure dose is low in almost all inhabitants. To prevent unnecessary "radiophobia" among inhabitants, it is important to provide accurate information on current radiation body burden, as well as on its health effects on the human body. 
Table 1. Study participants

\begin{tabular}{|c|c|c|c|c|c|c|c|c|c|c|c|c|}
\hline & & 1998 & 1999 & 2000 & 2001 & 2002 & 2003 & 2004 & 2005 & 2006 & 2007 & 2008 \\
\hline \multicolumn{2}{|c|}{ Total number } & 6776 & 6954 & 6508 & 9617 & 10828 & 11187 & 5688 & 6889 & 6824 & 6549 & 6846 \\
\hline \multirow{3}{*}{$\begin{array}{c}\text { Age } \\
\text { (years) }\end{array}$} & Median & 14 & 14 & 14 & 14 & 13 & 13 & 16 & 17 & 17 & 16 & 16 \\
\hline & $\begin{array}{c}25^{\text {th }} \\
\text { percentile }\end{array}$ & 12 & 13 & 13 & 11 & 10 & 10 & 13 & 14 & 14 & 13 & 12 \\
\hline & $\begin{array}{c}75^{\mathrm{th}} \\
\text { percentile }\end{array}$ & 16 & 16 & 16 & 16 & 15 & 15 & 18 & 35 & 34 & 33 & 32 \\
\hline \multirow{2}{*}{ Female } & Number & 3382 & 3646 & 3359 & 4900 & 5594 & 5705 & 3160 & 3763 & 3527 & 3392 & 3689 \\
\hline & $(\%)$ & $(49.9)$ & $(52.4)$ & $(51.6)$ & $(51.0)$ & $(51.7)$ & $(51.0)$ & $(55.6)$ & $(54.6)$ & $(51.7)$ & $(51.8)$ & $(53.9)$ \\
\hline
\end{tabular}


Table 2. Seasonal differences in ${ }^{137} \mathrm{Cs}$ concentration in the body $(\mathrm{Bq} / \mathrm{kg})$ for each year

\begin{tabular}{|c|c|c|c|c|c|c|c|}
\hline & & 1998 & 1999 & 2000 & 2001 & 2002 & 2003 \\
\hline March-May & $\begin{array}{c}\text { Median } \\
(\min -\mathbf{m a x})\end{array}$ & $\begin{array}{c}33.2 \\
(\mathrm{ND}-837.4)\end{array}$ & $\begin{array}{c}42.7 \\
(\mathrm{ND}-2154.9)\end{array}$ & $\begin{array}{c}33.5 \\
(\mathrm{ND}-1580.7)\end{array}$ & $\begin{array}{c}28.8 \\
(\mathrm{ND}-876.6)\end{array}$ & $\begin{array}{c}26.5 \\
(\mathrm{ND}-2240.8)\end{array}$ & $\begin{array}{c}18.4 \\
(\mathrm{ND}-734.1)\end{array}$ \\
\hline June-Aug & $\begin{array}{c}\text { Median } \\
(\min -\mathbf{m a x})\end{array}$ & $\begin{array}{c}77.7 \\
(14.4-399.0)\end{array}$ & $\begin{array}{c}20.7 \\
\text { (ND-102.9) }\end{array}$ & $\begin{array}{c}\text { ND } \\
\text { (ND-ND) }\end{array}$ & $\begin{array}{c}35.6 \\
\text { (ND-79.0) }\end{array}$ & $\begin{array}{c}\text { ND } \\
(\mathrm{ND}-56.0)\end{array}$ & $\begin{array}{c}42.4 \\
(\mathrm{ND}-393.0)\end{array}$ \\
\hline Sept-Nov & $\begin{array}{c}\text { Median } \\
(\min -m a x)\end{array}$ & $\begin{array}{c}59.9 \\
(\mathrm{ND}-2222.1)\end{array}$ & $\begin{array}{c}42.8 \\
(\mathrm{ND}-2521.7)\end{array}$ & $\begin{array}{c}40.6 \\
(\mathrm{ND}-1457.7)\end{array}$ & $\begin{array}{c}29.6 \\
(\mathrm{ND}-1707.0)\end{array}$ & $\begin{array}{c}23.5 \\
(\mathrm{ND}-650.2)\end{array}$ & $\begin{array}{c}35.6 \\
(\mathrm{ND}-1089.3)\end{array}$ \\
\hline Dec-Feb & $\begin{array}{c}\text { Median } \\
(\min -\mathbf{m a x})\end{array}$ & $\begin{array}{c}42.7 \\
(\mathrm{ND}-906.7)\end{array}$ & $\begin{array}{c}43.5 \\
(\mathrm{ND}-926.4)\end{array}$ & $\begin{array}{c}30.4 \\
(\mathrm{ND}-1735.8)\end{array}$ & $\begin{array}{c}26.2 \\
(\mathrm{ND}-926.0)\end{array}$ & $\begin{array}{c}24.0 \\
(\mathrm{ND}-387.5)\end{array}$ & $\begin{array}{c}\text { ND } \\
(\mathrm{ND}-534.4)\end{array}$ \\
\hline
\end{tabular}

\begin{tabular}{|c|c|c|c|c|c|c|}
\hline & & 2004 & 2005 & 2006 & 2007 & 2008 \\
\hline March-May & $\begin{array}{c}\text { Median } \\
(\min -m a x)\end{array}$ & $\begin{array}{c}37.3 \\
(\mathrm{ND}-5392.2)\end{array}$ & $\begin{array}{c}28.8 \\
(\mathrm{ND}-739.4) \\
\end{array}$ & $\begin{array}{c}24.6 \\
(\mathrm{ND}-1757.1) \\
\end{array}$ & $\begin{array}{c}30.9 \\
(\mathrm{ND}-601.8)\end{array}$ & $\begin{array}{c}38.8 \\
(\mathrm{ND}-1003.4)\end{array}$ \\
\hline June-Aug & $\begin{array}{c}\text { Median } \\
\text { (min-max) }\end{array}$ & $\begin{array}{c}\text { ND } \\
(\mathrm{ND}-62.0)\end{array}$ & $\begin{array}{c}29.8 \\
(\mathrm{ND}-180.9)\end{array}$ & $\begin{array}{c}19.6 \\
(\mathrm{ND}-271.1)\end{array}$ & $\begin{array}{c}\text { ND } \\
(\mathrm{ND}-21.0)\end{array}$ & $\begin{array}{c}26.9 \\
(\mathrm{ND}-69.5) \\
\end{array}$ \\
\hline Sept-Nov & $\begin{array}{c}\text { Median } \\
(\text { min-max) }\end{array}$ & $\begin{array}{c}48.1 \\
(\mathrm{ND}-1035.0)\end{array}$ & $\begin{array}{c}32.5 \\
(\mathrm{ND}-625.1)\end{array}$ & $\begin{array}{c}37.6 \\
(\mathrm{ND}-2229.3)\end{array}$ & $\begin{array}{c}47.2 \\
(\mathrm{ND}-366.4)\end{array}$ & $\begin{array}{c}50.2 \\
(\mathrm{ND}-396.3)\end{array}$ \\
\hline Dec-Feb & $\begin{array}{l}\text { Median } \\
(\min -\mathbf{m a x})\end{array}$ & $\begin{array}{c}14.9 \\
(\mathrm{ND}-358.1)\end{array}$ & $\begin{array}{c}22.0 \\
(\mathrm{ND}-607.0)\end{array}$ & $\begin{array}{c}20.1 \\
(\mathrm{ND}-1454.3)\end{array}$ & $\begin{array}{c}42.7 \\
(\mathrm{ND}-348.7)\end{array}$ & $\begin{array}{c}45.4 \\
(\mathrm{ND}-500.1)\end{array}$ \\
\hline
\end{tabular}

ND: not detected 
Table 3. Seasonal differences in ${ }^{137} \mathrm{Cs}$ concentration in the body $(\mathrm{Bq} / \mathrm{kg})$ and the number of participants

\begin{tabular}{|c|c|c|c|c|}
\hline & & 1998-2001 & 2002-2005 & 2006-2008 \\
\hline \multirow{3}{*}{ March-May } & Median & 34.6 & 27.3 & 32.0 \\
\hline & $(\min -\max )$ & (ND-2154.9) & (ND-5392.2) & (ND-1757.1) \\
\hline & Number & 10993 & 18722 & 9284 \\
\hline \multirow{3}{*}{ June-Aug } & Median & $71.5^{*}$ & 32.2 & 21.2 \\
\hline & $(\min -\max )$ & (ND-399.0) & (ND-393.0) & (ND-271.1) \\
\hline & Number & 265 & 268 & 451 \\
\hline \multirow{3}{*}{ Sept-Nov } & Median & 40.9 & $33.5^{* *}$ & $44.2^{* * *}$ \\
\hline & $(\min -\max )$ & (ND-2521.7) & (ND-1089.3) & (ND-2229.3) \\
\hline & Number & 9590 & 8999 & 4080 \\
\hline \multirow{3}{*}{ Dec-Feb } & Median & 33.5 & 20.6 & 39.8 \\
\hline & $(\min -\max )$ & (ND-1735.8) & (ND-607.0) & (ND-1454.3) \\
\hline & Number & 8971 & 6603 & 6404 \\
\hline
\end{tabular}

ND: not detected

${ }^{*} \mathrm{p}<0.001$ vs. March-May, Sept-Nov, Dec-Feb, during 1998-2001.

${ }^{* *} \mathrm{p}<0.001$ vs. March-May, June-Aug, Dec-Feb, during 2002-2005.

$* * * \mathrm{p}<0.001$ vs. March-May, June-Aug, Dec-Feb, during 2006-2008. 
Table 4. Number of participants with each annual internal exposure dose (mSv)

\begin{tabular}{|c|c|c|c|c|c|c|c|c|c|c|c|}
\hline & 1998 & 1999 & 2000 & 2001 & 2002 & 2003 & 2004 & 2005 & 2006 & 2007 & 2008 \\
\hline$<0.1 \mathrm{mSv}$ & 3173 & 3149 & 3750 & 6371 & 7604 & 7907 & 2891 & 4385 & 4360 & 3404 & 2965 \\
\hline$\geq 0.1 \mathrm{mSv}$ & 3505 & 3754 & 2691 & 3208 & 3206 & 3238 & 2770 & 2504 & 2403 & 3139 & 3881 \\
\hline$\geq 1 \mathrm{mSv}$ & 97 & 49 & 67 & 38 & 17 & 42 & 26 & 0 & 60 & 6 & 0 \\
\hline$(\%)$ & $(1.43)$ & $(0.71)$ & $(1.03)$ & $(0.40)$ & $(0.16)$ & $(0.38)$ & $(0.46)$ & (0) & $(0.88)$ & $(0.09)$ & $(0)$ \\
\hline$\geq 5 \mathrm{mSv}$ & 1 & 2 & 0 & 0 & 1 & 0 & 1 & 0 & 1 & 0 & 0 \\
\hline
\end{tabular}


Table 5. Calculated 50-year exposure dose commitment of ${ }^{137} \mathrm{Cs}(\mathrm{mSv})$

\begin{tabular}{c|ccccccccccc} 
& $\mathbf{1 9 9 8}$ & $\mathbf{1 9 9 9}$ & $\mathbf{2 0 0 0}$ & $\mathbf{2 0 0 1}$ & $\mathbf{2 0 0 2}$ & $\mathbf{2 0 0 3}$ & $\mathbf{2 0 0 4}$ & $\mathbf{2 0 0 5}$ & $\mathbf{2 0 0 6}$ & $\mathbf{2 0 0 7}$ & $\mathbf{2 0 0 8}$ \\
\hline Median & 2.8 & 2.9 & 2.3 & 1.9 & 1.7 & 1.6 & 2.6 & 1.9 & 1.8 & 2.6 & 2.9 \\
$(\min -\max )$ & $(0-148.6)$ & $(0-168.6)$ & $(0-116.1)$ & $(0-114.1)$ & $(0-149.8)$ & $(0-72.8)$ & $(0-360.6)$ & $(0-49.4)$ & $(0-149.1)$ & $(0-40.2)$ & $(0-67.1)$
\end{tabular}




\section{References}

1. Hoshi M., Konstantinov Y. O., Evdeeva T. Y., Kovalev A. I., Aksenov A. S., Koulikova N.V., Sato H., Takatsui T., Takada J. and Yamashita S. Radiocesium in children residing in the western districts of the Bryansk Oblast from 1991-1996. Health Phys. 79: 182-186 (2000).

2. International Atomic Energy Agency. Chernobyl's Legacy: Health, Environmental and Socio-Economic Impacts and Recommendation to the Governments of Belarus, the Russian Federation and Ukraine, The Chernobyl Forum 2003-2005. International Atomic Energy Agency, Vienna (2006).

3. Bennett B., Repacholi M. and Carr Z. Health Effects of the Chernobyl Accident and Special Health Care Programmes, Report of the UN Chernobyl Forum Expert Group "Health." World Health Organization, Geneva (2006).

4. Yamashita S. and Shibata Y. Chernobyl A Decade. ICS 1156, Elsevier, Amsterdam (1997).

5. Kazakov V. S., Demidchik E. P. and Astakhova L. N. Thyroid Cancer after Chernobyl. Nature 359, 21 (1992).

6. Souchkevitch G. N. and Tsyb A. F. Health Consequences of the Chernobyl Accident: Results of the IPEHCA Pilot Projects and Related National Programmes. World Health Organization, Geneva (1997).

7. Cardis E., Howe G., Ron E., Bebeshko V., Bogdanova T., Bouville A., Carr Z., Chumak V., Davis S., Demidchik Y. et al. Cancer consequences of the Chernobyl accident: 20 years on. J. Radiol. Prot. 26, 127-140 (2006).

8. Hoshi M., Shibata Y., Okajima S., Takatsuji T., Yamashita S., Namba S., Yokoyama N., Izumi M., Nagataki S., Fujimura K. et al. ${ }^{137}$ Cs concentration among children in areas contaminated with radioactive fallouts from the Chernobyl accident: Mogilev and Gomel oblasts, Belarus. Health Phys. 67: 272-275 (1994).

9. Morita N., Takamura N., Ashizawa K., Shimasaki T., Yamashita S. and Okumura Y. Measurement of the whole-body ${ }^{137} \mathrm{Cs}$ in residents around the Chernobyl nuclear power plant. Radiat. Prot. Dosimetry 113, 326-329 (2005).

10. ICRP Recommendations of the International Commission on Radiological Protection. Publication 60, Annals of the ICRP 21, Elsevier (1990).

11. Hille R., Hill P., Heinemann K., Ramzaev V., Barkovski A., Konoplia V., and Neth R. 
Current development or the human and environmental contamination in the Bryansk-Gomel spot after the Chernobyl accident. Radiat. Environ. Biophys. 39, 99-109 (2000).

12. Skuterud L., Travnikova I. G., Balonov M. I., Strand P. and Howard B. J. Contribution of fungi to radiocesium, intake by rural populations in Russia. Sci. Total Environ. 193, 237-242 (1997).

13. Jesko T., Zvonova I., Balonov M., Thornberg C., Mattsson S., Wallstrom E., Vesanen R. and Alpsten M. Age-dependent dynamics of cesium radionuclide content in inhabitants of the Bryansk region, Russia: A seven-year study. Radiat. Prot. Dosimetry 89, 179-182 (2000).

14. Travnikova I. G., Bruk G. J., Shutov V. N., Bazjukin A. B., Balonov M. I., Rahola T. and Tillander M. Contribution of different foodstuffs to the internal exposure of rural inhabitants in Russia after the Chernobyl accident. Radiat. Prot. Dosimetry 93, 331-339 (2001).

15. Thornberg C., Vesanen R., Wallström E., Zvonova I., Jesko T., Balonov M. and Mattsson S. External and internal radiation exposure of a rural Bryansk (Russia) population from 1990 to 2000, following high deposition of radioactive cesium from the Chernobyl accident. Radiat. Environ. Biophys. 44, 97-106 (2005).

16. United Nations Scientific Committee on the Effects of Atomic Radiation. Report to the General Assembly, with Scientific Annex. ISBN 92-1-142219-1, Vienna (1996).

17. Bouville A., Likhtarev I. A., Kovgan L.N., Minenko V. F., Shinkarev S. M. and Drozdovitch V. V. Radiation dosimetry for highly contaminated Belarusian, Russian and Ukrainian populations, and for less contaminated populations in Europe. Health Phys. 93, 487-501 (2007). 


\section{Figure legends}

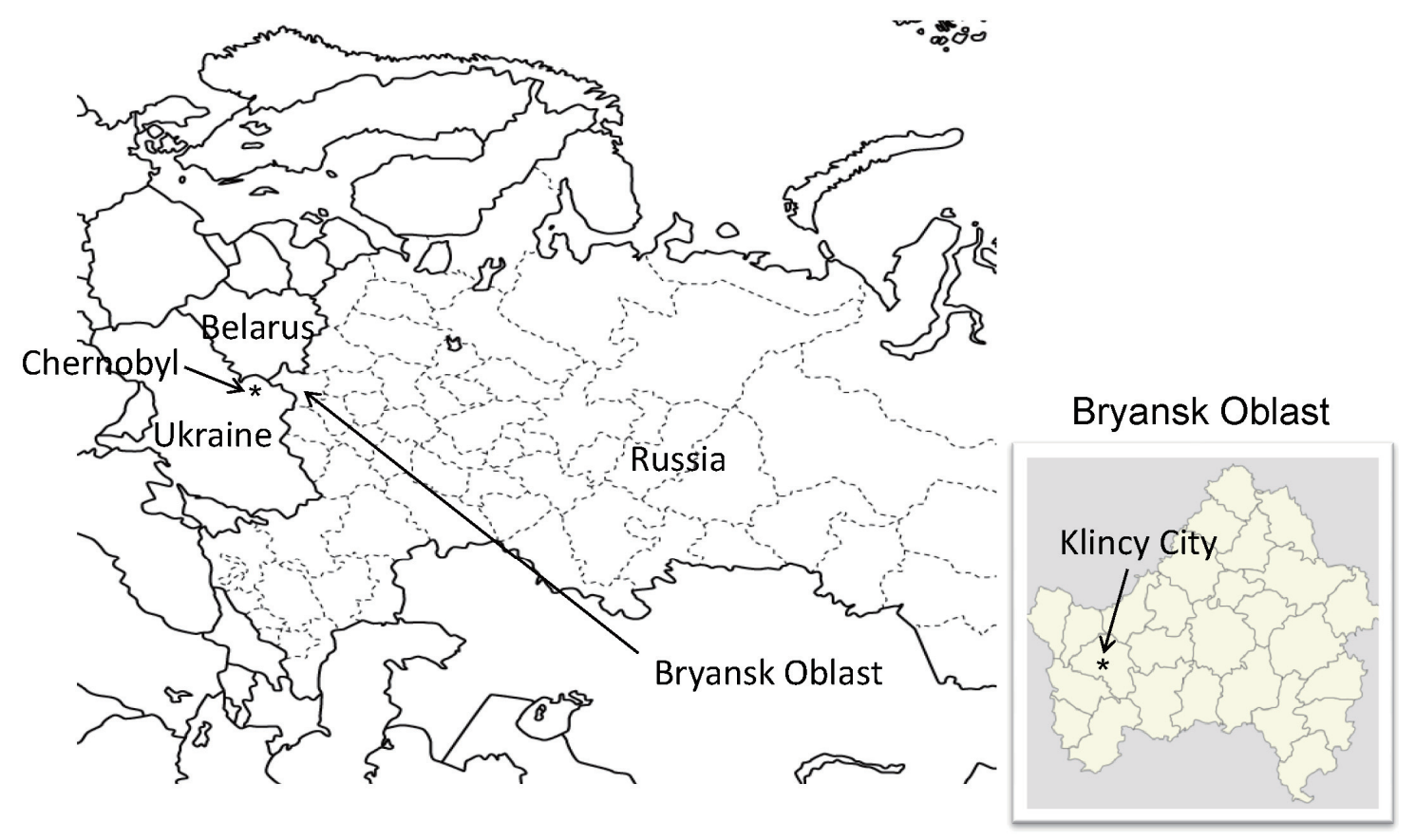

Fig. 1: Location of Bryansk Oblast, Russian Federation.

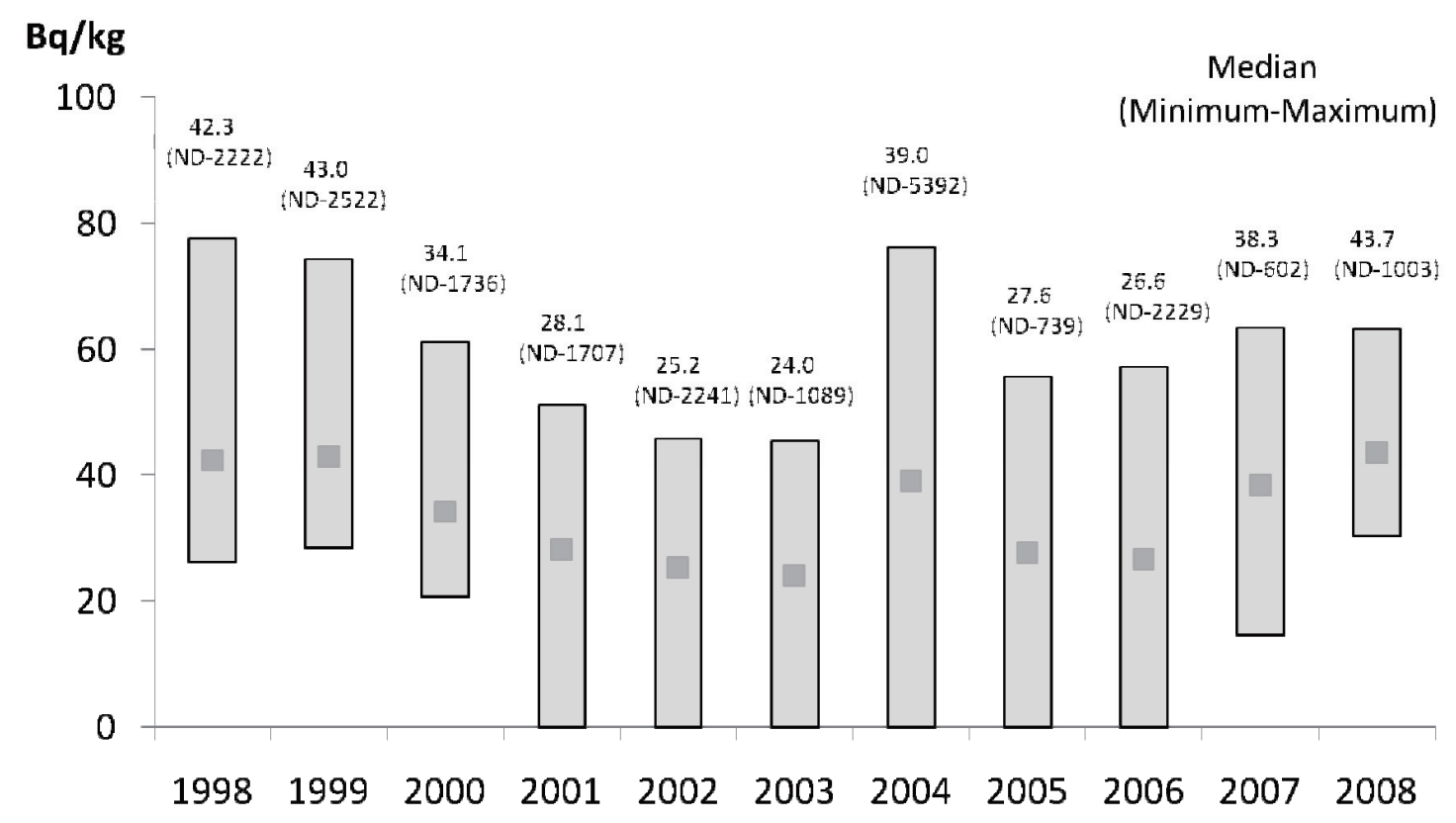

ND: not detected

Fig. 2: Box and plot of ${ }^{137} \mathrm{Cs}$ concentrations evaluated by whole-body counter. The ends of the box indicate the positions of the $25^{\text {th }}$ and $75^{\text {th }}$ percentiles of the data, and the plot in the box indicates the median. 